\title{
Future wave climate driven longshore sediment transport along the Indian coast
}

\author{
Piyali Chowdhury $^{1 *}$, Manasa Ranjan Behera ${ }^{1,2}$, Dominic E. Reeve ${ }^{3}$ \\ ${ }^{1}$ Inter Disciplinary Program in Climate Studies, Indian Institute of Technology Bombay, Mumbai- \\ 400076, India \\ ${ }^{2}$ Department of Civil Engineering, Indian Institute of Technology Bombay, Mumbai-400076, India \\ ${ }^{3}$ College of Engineering, Swansea University, Swansea-SA2 8PP, UK \\ Current address of corresponding author: "School of Engineering, University of Plymouth, Drake \\ Circus, Plymouth, PL4 8AA, United Kingdom
}

\begin{abstract}
Longshore sediment transport is an important nearshore process that governs coastal erosion/accretion and in turn, defines the orientation of coastlines. In this study, we assess the changes in longshore transport rates along the Indian coast due to the potential changes in wave parameters under the RCP4.5 climate scenario. The projected wave climate for two time slices, "near-term/present" (2011-2040) and "mid-term/future" (2041-2070) were used to investigate changes in the corresponding sediment transport rates. An empirical model accounting for major wave parameters, longshore current, resulting sediment transport, and shoreline evolution, was used. It was found that most of the Indian coast exhibited the same drift direction in both time slices, although changes in transport magnitude were present. To give a broadbrush characterisation of the coastline, the shoreline elements were classified as erosive, accretive or stable based on the comparative longshore transport rates of neighbouring elements. Similar characterisations, carried out for both time slices showed that about $35 \%$ of the total coastline would remain unaffected due to the changing wave climate in future (i.e. there is little to no change); about $20 \%$ is expected to "worsen" (i.e. expected to undergo higher magnitudes of erosion wrt present rate); and $45 \%$ to "improve" (i.e. expected to accrete/reach stability). It was also observed that the net annual transport rates pertaining to the future period are not expected to change significantly with respect to the current scenario. This indicates that the change in longshore transport rates arising from future changes in wave climate as represented by the RCP4.5 climate change scenario will have a broadly neutral effect.
\end{abstract}

Keywords: Climate change; Wave climate; Longshore sediment transport; Coastal vulnerability; Indian coast 


\section{Introduction}

Coastal communities are expected to be under potential threat due to changes in wave climate (Zsamboky et al. 2011; Nicholls et al. 2018). These variations are expected to impact the coastal processes, such as, sediment transport. The impact of global climate change on nearshore wave climate and consequently on various coastal processes, like inundation, erosion, accretion, sediment transport, amongst others, have been widely reported from all over the world. For example, Zacharioudaki and Reeve (2011) studied the impact of future waves along central coasts of England; Almar et al. (2015) investigated the long-term effects of wave climate variations on sediment transport along West Africa; Dastgheib et al. (2016) studied the variations in future wave climate and its impact on Vietnam coast; Chowdhury and Behera (2017) investigated the effects of a changing wave climate along central west coast of India. It is also reported that global climate change will not only impact the natural processes but also the economy of the impacted regions (e.g., Nicholls et al. 2018). The coastal environment consists of a complex ecosystem which provides economic benefits to the communities living there. To plan effective adaptation measures it is necessary to assess the oceanographic and morphologic changes expected to occur in the near future. Any future coastal zone management plans may then incorporate the projected changes in coastal wave climate and the corresponding coastal morphological changes into the broader planning framework.

The coastal ecosystem is dynamic in nature and is constantly adjusting to large scale meteorological fluctuations, (such as seasonal and longer term variations), and anthropogenic interventions, (such as the construction of ports and harbours, coastal defence structures). Although coastal vulnerability is mainly assessed with respect to sea level changes, it is not the only driver of physical processes in the nearshore zone. Also, the main focus of this study is to analyse future wave-driven longshore transport along the Indian coast. It is well established (e.g. Bengtsson et al. 2006; Wang et al. 2009), that there is a possibility of changes in ocean wave climate as we approach the end of this century, and the changing wave climate would impact heavily on the nearshore processes. Pattiaratchi et al. (1997) reported that even with slight increase in wave heights, there is a possibility of increased incident wave energy at the beaches, causing at least ten to hundred times increase in the longshore sediment transport. With global climate change, it is expected that ocean wave climate will also undergo changes at global as well as local/regional scales. Many studies have reported that changes in ocean wave climate are detectable, but Adams et al. (2011) 
have argued that translating these changes to nearshore processes is a complex task. However, the quantitative prediction of coastal processes is now possible due to the wellestablished empirical and numerical models, but the accuracy of prediction will depend on the environmental conditions at the nearshore zone and the governing physical processes (Güner et al. 2011). Longshore sediment transport is the most important coastal process that shapes coastal geomorphology, (CERC 1984). Methods of estimating longshore transport rates fall into two broad categories: bulk formulae (based on empirical formulae fitted to observations); and process based models which include a detailed description of the physical processes. A large number of input parameters are required for process based modelling, whereas the bulk formulae require only a characterisation of wave conditions in the breaker zone (Mil-Homens et al. 2012). Thus, bulk empirical formulae are widely used by many practitioners and researchers to estimate longshore sediment transport rates. However, it must be borne in mind that the investigation of the impacts of climatic changes on a natural system may inherit other uncertainties such as those arising from the nature of the emission scenarios, the choice of climate models, and the impact descriptors (Zacharioudaki and Reeve 2011).

The Central Water Commission (CWC) of India reported that an estimated 200 million people (about 16\% of the total population) live in coastal districts of India (CWC 2016). The Indian coast is subjected to annual and seasonal scale variations in wave climate due to the reversal of winds at the onset and termination of the monsoon. There are two major monsoon seasons in the northern Indian Ocean region: the south-west monsoon (June to September) and the north-east monsoon (October to December). The south-west monsoon dominates the ocean waves and the nearshore activities along the west coast of India, whereas both north-east and south-west monsoons are responsible for intense wave conditions along the east coast of India. With changes in seasonal wave climate, it is expected that the nearshore processes may also undergo changes, altering the magnitude and direction of longshore transport. It is also important to investigate the future changes in wave height and direction, as they determine the longshore transport rates at any given location and time, and hence govern the sediment dynamics and orientation of sandy beaches. It was reported in earlier studies, (e.g. Hemer et al. 2013; Mori et al. 2013), that the wave climate in the Northern Indian Ocean is expected to change as we move towards the end of the century. In a study of the whole Indian coast, Chowdhury et al. (2019) found that wave conditions are expected to change at a large scale with almost all locations showing an increase in the wave 
height and period. Wave directions were also noticed to have shifted (at some locations by as much as $22^{\circ}$ ) in the future years.

The Ministry of Environment, Forest and Climate Change, Government of India, delineated the Indian coast into 27 sediment cells. A sediment cell is defined as length of the coastline and associated near-shore areas where movement of sediments is largely selfcontained. There is no study reported so far that investigates the impact of future wave climate change on longshore sediment transport rates at local scales along the Indian coast. In this study, we investigate the potential effects of changes in future wave climate on the magnitudes of longshore transport rates and consequent coastal erosion and accretion at selected locations along the Indian coast (Figure 1). One or more locations were selected from each sediment cell to capture the local morphodynamics effectively. However, no points were selected from regions with marshy coasts (parts of Gujarat and West Bengal coastline).

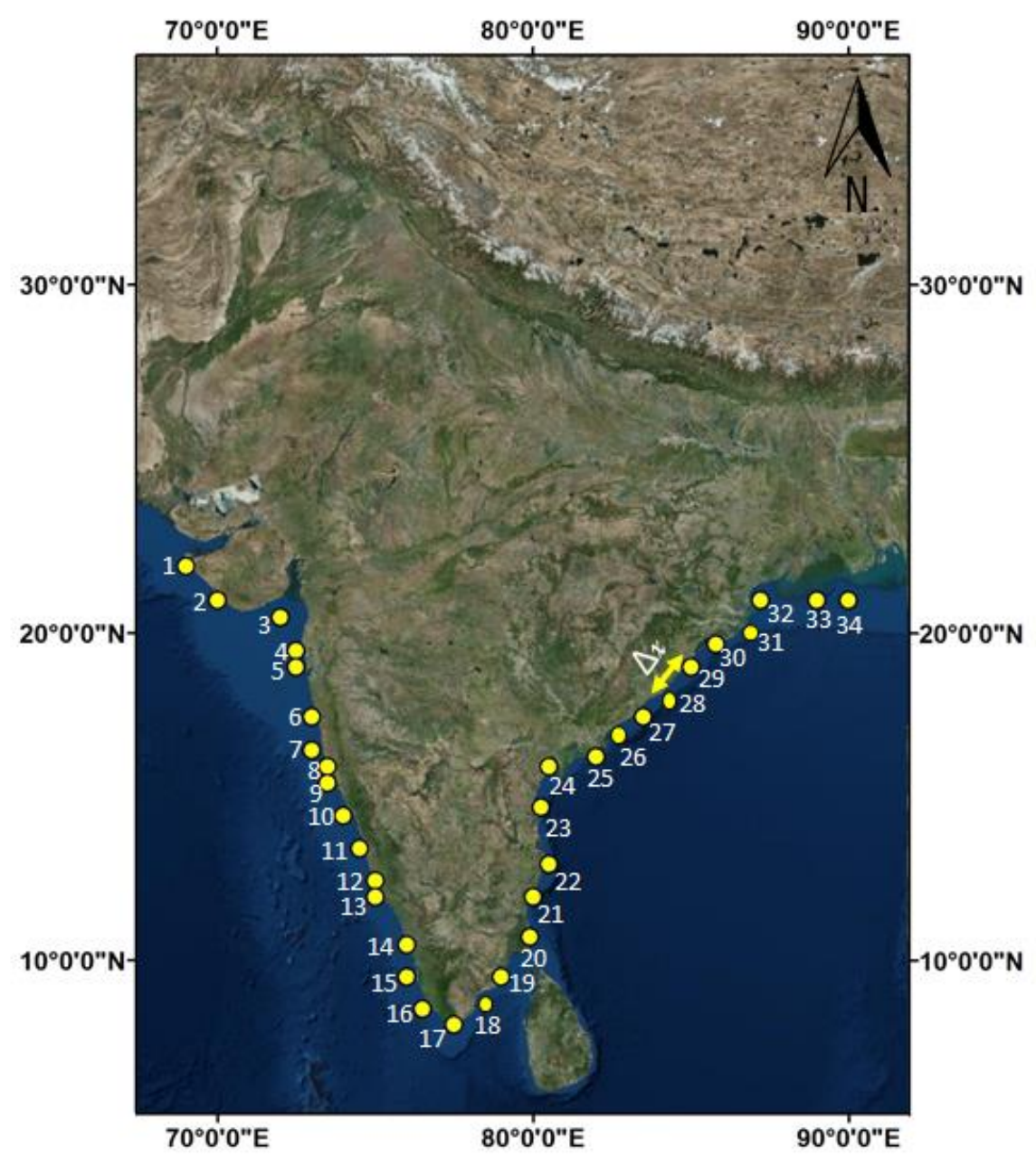

Figure 1: Selected locations for wave data extraction and longshore transport estimation along the Indian coast 
The CWC (2016) report, on the status of coastline along India, classified the mainland Indian coastline as highly vulnerable, with about $40 \%$ of its coast facing erosion and $34 \%$ facing accretion. The report revealed that around $73 \mathrm{~km}^{2}$ of area was lost due to coastal erosion, much of which was ecologically and financially important. This vulnerable state of Indian coastline puts almost $16 \%$ of its population under threat from coastal erosion. Figure 2 shows the classification of the Indian coast as erosive, accretive and stable (adapted from the CWC 2016 report), also the nine Indian coastal states, Gujarat, Maharashtra, Goa, Karnataka, Kerala, Tamil Nadu, Andhra Pradesh, Odisha, and West Bengal, are marked in the same figure for future reference.

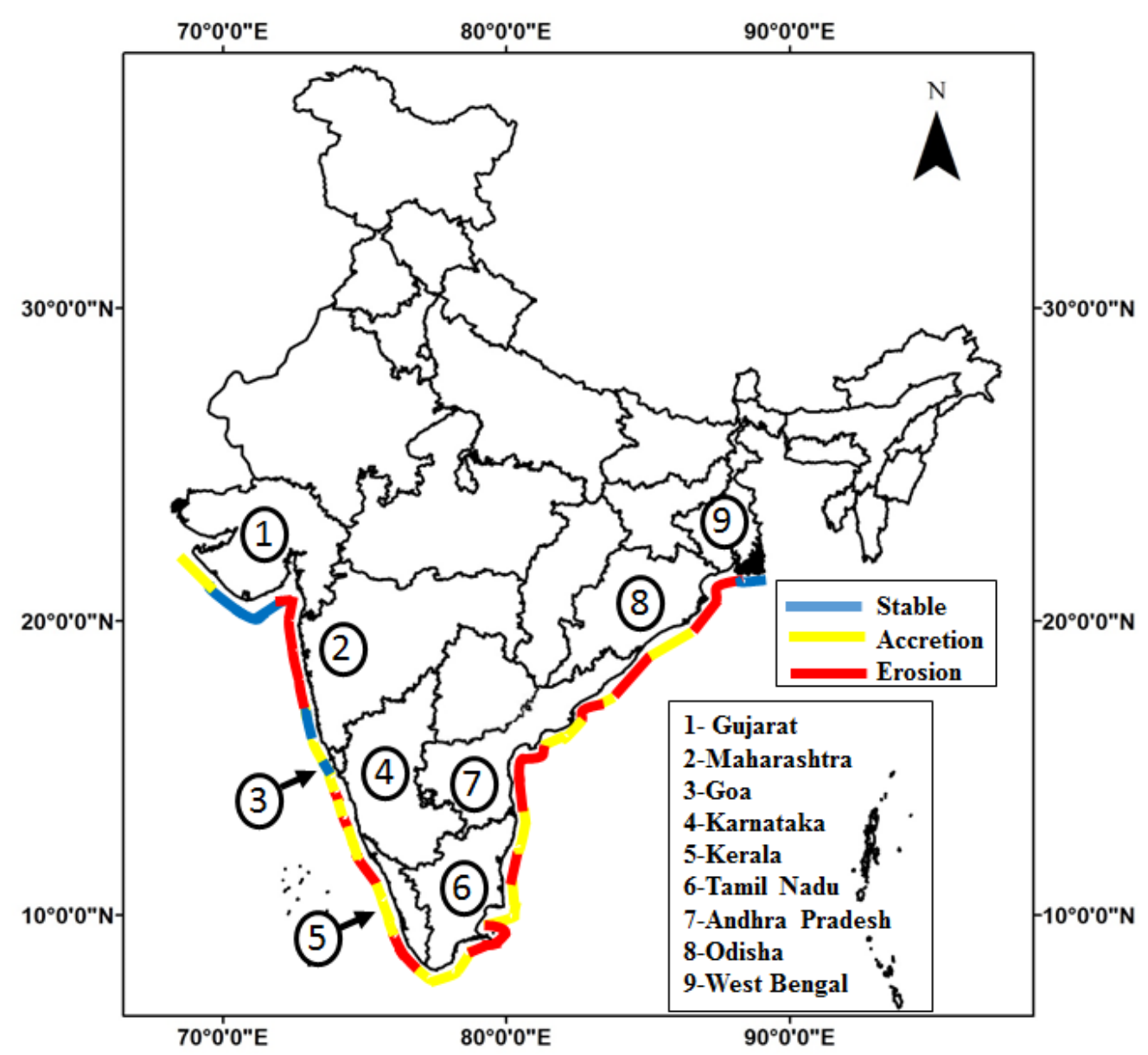

Figure 2: Classification of the Indian coast as erosive, accretive and stable stretches (as adapted from CWC, 2016)

Currently, researchers use different methods to study the impact of changing climate on the wave field. Such methods can be divided into: a) trend analysis of long-term measured or reconstructed wave data (e.g. Wang and Swail 2002) and b) future projections obtained from climate models (e.g. Grabemann and Weisse 2008; Chowdhury et al. 2019). Here, we 
use the projected wave climate for two time slices, 2011-2040 and 2041-2070, as reported in Chowdhury et al. (2019). The waves were simulated for the intermediate RCP4.5 scenario. RCP4.5 is an intermediate "stabilization without overshoot" pathway in which radiative forcing is stabilized at approximately $4.5 \mathrm{~W} / \mathrm{m}^{2}$ after 2100, (Moss et al. 2008). An ensemble wind dataset, obtained from four different General Circulation Models (GCMs), was used as input to drive the wave climate simulations over the Indian Ocean region. The potential impacts of the resulting future wave climate on coastal dynamics were studied in terms of changes in longshore transport and, in turn, the tendency of beaches towards erosion or accretion. A three-step longshore sediment transport model, as described in Chowdhury and Behera (2017), is used in this study.

This paper is structured as follows. First, the sources of data and the methods used to create the projected wave conditions are described, together with the parameters that characterize the beaches at different locations. The details of the wave analysis methods and methodology adopted for sediment transport modelling are presented in the 'Methodology' section. Following this the results are presented and discussed, and final conclusions are drawn.

\section{Data}

Wave climate: the forcing

To project the near-term and mid-term longshore transport scenarios, we use regional wave climate projections along the Indian coast. Wave climate for both the time slices were projected using a third generation spectral wave model, MIKE21 (DHI 2014). MIKE21 is an operational wave simulation model of the Danish Hydraulic Institute. It has been extensively validated for wave simulation over Indian Ocean region (Remya et al. 2012; Chowdhury and Behera 2018). The spectral wave model was forced with an ensemble of wind data, which was obtained from four different GCMs, namely GFDL, CSIRO, CNRM and IPSL, following Chowdhury et al. (2019). A simple averaging method was used to obtain the ensemble from GCMs. The selected GCM wind outputs (with varying grid resolution) were downscaled to a common resolution of $0.5^{\circ} \times 0.5^{\circ}$ using bilinear interpolation. The downscaled wind data was then corrected for bias using the quantile mapping method explained by Li et al. (2010). This method is based on equating the cumulative distribution functions (CDFs) of a given approximate dataset with that of a more reliable one (in this case ERA-Interim reanalysis data, following Chowdhury and Behera 2018). 
The wave model is based on an unstructured flexible mesh which allows simultaneous computation on regional to local scales, in which time integration is performed using the fractional step approach. The wave model was applied over the entire Indian Ocean region ranging from $30^{\circ} \mathrm{N}$ to $40^{\circ} \mathrm{S}$ and $20^{\circ} \mathrm{E}$ to $110^{\circ} \mathrm{E}$ with variable resolutions (coarse grid in deeper ocean to finer resolution in coastal regions), in order to incorporate the swells arriving from the Southern Indian Ocean, as these swells highly influence the nearshore wave climate along the Indian coast. MIKE21 produces phase averaged wave parameters as output over the computational area. The daily wave characteristics were used to obtain the annual means at each selected locations. Then the annual means were used to obtain the time slice mean which were then analysed for impact of climate change on waves.

\section{Coasts: the receptor}

Around $46 \%$ of the total Indian coast is eroding, approximately $36 \%$ is accreting and the remainder is categorized as stable (CWC 2016). Sediment transport not only depends on the waves but also on the local geomorphology of the coast. Indian coastline consists of numerous river mouths, headlands, cliffs, bays, creeks, lagoons, and sandy beaches. Sandy beaches account for about $43 \%$ of the total coastline (Mukhopadhyay and Karisiddaiah 2014). In general, the east coast comprises long stretches of sandy beaches backed by dunes, whereas much of the west coast is indented with rocky headlands, pocket beaches and multiple estuaries. The continental shelf along the east coast is narrow compared to the west coast, which has a shallower and wider shelf.

In the present study, we investigated the impact of a changing wave climate on longshore sediment transport, along the Indian coast. The daily bulk wave parameters; wave height, period and direction were obtained from the wave model, and used as input to the longshore sediment transport model. The estimated annual longshore transport values were then used as input to the shoreline evolution model to obtain the rate of erosion and accretion along the Indian coast. The rates of erosion or accretion were presented in terms of 30 year time-slice means to compare the status of the Indian coast under the climate change scenario. Since the aim of the study is to investigate the impact on a regional scale, some assumptions were made to simplify the complexity of the problem in hand. First, the selected locations were assumed to be sandy beaches, where the considered bulk formula (Kaczmarek et al. 2005 ) is applicable. The Kaczmarek et al. (2005) formula was used for sediment transport modelling due to its suitability for remote sites such as the Indian coast where only limited 
observations exist. Second, to simplify the irregularity of the coast, the locations were assumed to have straight coastlines and presence of any cliffs, estuaries, creeks or coastal structures was neglected. Locations in the Gulf of Khambhat, Gulf of Kutch, and Sundarbans regions were not considered for the analysis, as they have a highly irregular coastline, marshy coasts and complex dynamics. Moreover, the influence of tides in maintaining the annual sediment budget in these regions is significant, and the methods used in the present study does not consider sediment transport induced due to tidal currents. Thus, these regions require a more detailed localised study.

\section{Methodology}

\section{Wave climate analysis}

Daily wave heights $\left(\mathrm{H}_{\mathrm{s}}\right)$, periods $\left(\mathrm{T}_{\mathrm{p}}\right)$ and directions $\left(\theta_{\mathrm{m}}\right)$ were extracted at the selected locations along the Indian coast as shown in Figure 1, thereafter; annual means of these wave characteristics were obtained. The means of present and future wave climate were then used to compare and identify any changes under the global warming scenario.

\section{Coastal morphodynamics}

The potential impact of the near- and mid-term wave climate on shoreline dynamics was determined by comparing the corresponding longshore transport rates, as the longshore transport rates at a given location can be a good indicator of the tendency towards retreat (erosion) or accretion (U.S. Army Corps of Engineers, 2002). The average annual wave parameters were used to compute estimates of potential longshore transport.

The Kaczmarek et al. (2005) bulk formula was used to estimate longshore sediment transport. The basic assumptions common to all one-line models apply. That is, the beach profiles are considered to be and remain in equilibrium, changes in shoreline position are due to gradients in longshore transport, there is an adequate sand supply, sediment transport is always alongshore due to the action of breaking waves and longshore currents, and feedback of changes in beach morphology on the incoming waves is ignored.

The volume of longshore sediment transport depends on the longshore current which is generated due to the breaking of waves and hence has a seasonal to annual variation. The Kaczmarek et al. (2005) formula used in this study, assumes longshore sediment transport to be proportional to the longshore wave energy flux, as given in Eq. (1). Bertin et al. (2008) tested this formula for a wave-dominated coastal region by comparing the model results with 
field measurements carried out using tracers. They found that transport rates deduced from tracer experiments were in good agreement with the estimates using Kaczmarek et al. (2005) formula. This formula was also applied to other similar coastal environments successfully by others (e.g. Castelle et al. 2009; Almar et al. 2015), and tested for few locations around Indian coast (Chowdhury and Behera 2017; Chowdhury and Behera 2019). The formula is:

$\mathrm{Q}=\left\{\begin{array}{c}0.023\left(H_{b}^{2} V\right)\left[\mathrm{m}^{3} / \mathrm{s}\right], \text { if, } H_{b}^{2} V<0.15 \text { (low and medium wave climate) } \\ 0.00225+0.008\left(H_{b}^{2} V\right)\left[\mathrm{m}^{3} / \mathrm{s}\right], \text { if, } H_{b}^{2} V>0.15 \text { (higher waves and storms) }\end{array}\right.$

where $\mathrm{Q}$ is the volume of total sediment transport ( $\mathrm{m}^{3} /$ year), $\mathrm{H}_{\mathrm{b}}$ is the breaker wave height and $\mathrm{V}$ is the average longshore current velocity in the surf zone which is determined using Longuet-Higgins (1970) formula as below:

$$
V=0.25 k_{v} \sqrt{\gamma_{b} g H_{b}} \sin 2 \theta_{b}[\mathrm{~m} / s]
$$

where $\gamma_{b}$ is the constant wave breaker parameter (taken to be 0.78), $g$ is the gravitational acceleration, $\theta_{b}$ is breaker wave angle and $k_{v}$ is an empirical constant. Considering the difficulties presented by the spatio-temporal scales of this study, we used the empirical breaking wave predictor formula proposed by Larson et al. (2010) to propagate waves from deep water to the breaking point. This formula computes the breaker wave height $\left(\mathrm{H}_{\mathrm{b}}\right)$ and angle $\left(\theta_{\mathrm{b}}\right)$ using deep water wave height, period and direction, obtained from the spectral wave model, assuming a plane sloping seabed.

A three-step holistic sediment transport model, as described in Chowdhury and Behera (2017) and depicted in Figure 3, is used in this study. The annual average wave conditions at each location were used in Equation (1) to estimate the mean rate of sediment transport. Differences in the computed longshore transport rates then provided an insight into the relative stability of these shoreline elements under the changing wave climate. To achieve this, the longshore transport values obtained from our analysis were used to classify the coastal stretches as accreting, eroding or stable. The classification of stretches for the nearand mid-term wave climate scenario was based on the information on the current state of longshore transport rates along the Indian coast, as obtained from a detailed report on the status of Indian beaches which was published by the Government of India (CWC 2016). The estimates given in this report are based on data from different spatial and temporal scales (1989-1991 and 2004-2006) from that of the present study. The results presented in this 
report are used as reference for comparing the longshore sediment transport rates in the two time slices as considered in this study.

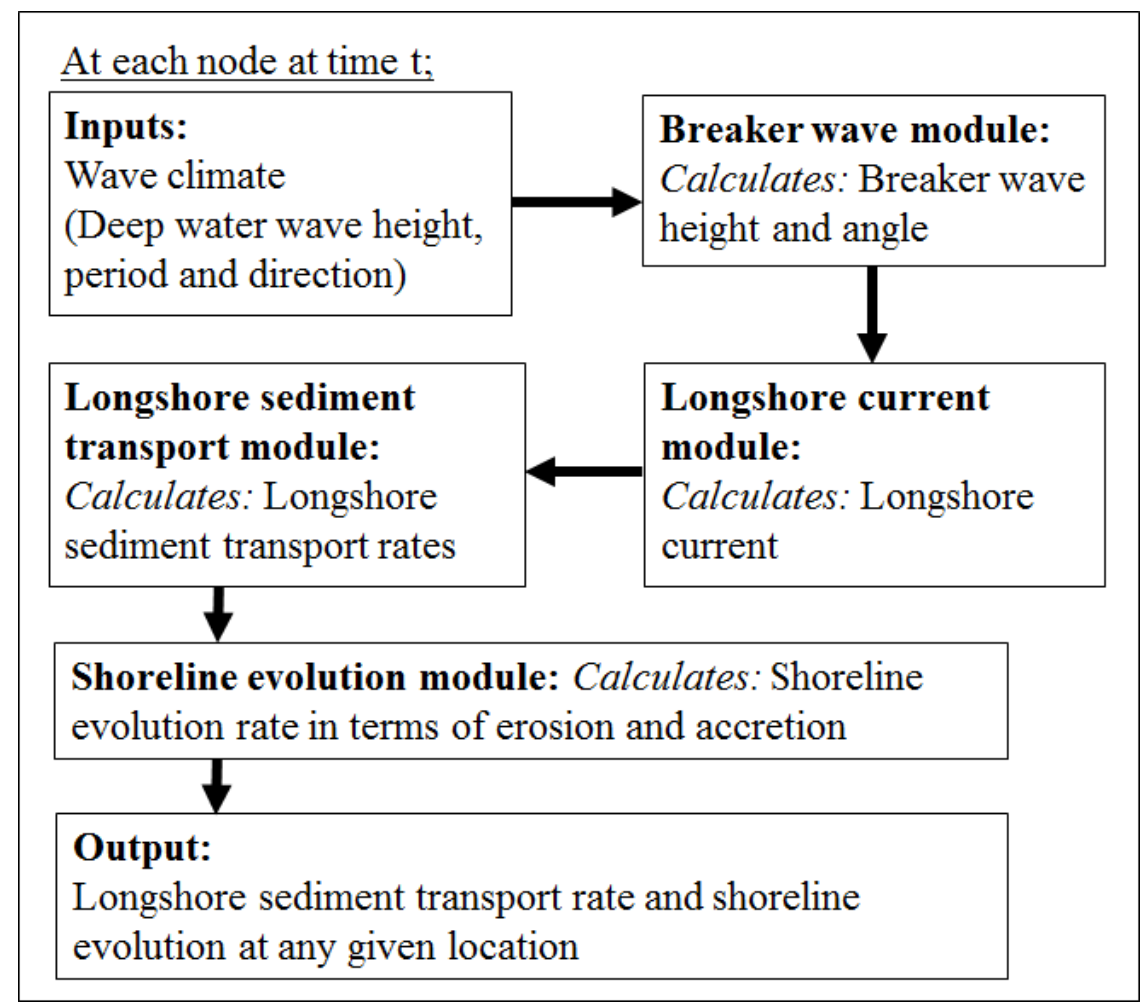

Figure 3: Schematic diagram of the sediment transport modelling procedure

In addition to estimating the temporal rate of change of longshore transport due to changes in wave climate, we also investigated the large scale spatial variations in longshore transport and the inferred tendency of the shorelines towards erosion or accretion. The tendency of the selected stretches (distance between two locations as denoted by $\Delta x$ in Figure 1) towards erosion/accretion was estimated using the continuity equation (Eq. 3), as given in Slott et al. (2006):

$$
\frac{d \eta}{d t}=\left(\frac{-1}{D_{a v g}}\right)\left(\frac{\Delta Q}{\Delta x}\right)
$$

where $\eta$ is the shoreline position, such that $d \eta / d t$ gives an indication of accretion/erosion, $\Delta \mathrm{Q} / \Delta x$ is the gradient of longshore transport which is approximated by taking the difference of rate of longshore sediment transport (Q) between two consecutive locations divided by the distance $(\Delta x$ in $\mathrm{m})$ between those values. $\Delta x$, is the linear distance between two selected locations, and $\mathrm{D}_{\text {avg }}$ is the average of two consecutive local depths of closure, below which no considerable profile change takes place, which is calculated using Eq. 4 as given by Hallermeier (1978): 


$$
D=2.28 H_{S}-68.5 \frac{H_{S}^{2}}{g T^{2}}[m]
$$

\section{Results and Discussions}

Present and future wave climate

Figure 4 compares the near- and mid-term wave climate. $H_{s}$ and $T_{p}$ averaged over each time slice (30 years) at the selected locations. It is observed from Figure 4(a) that the wave heights at almost all the locations along the Indian coast would increase as we move into the future time slice (by more than $20 \%$ at some locations). The wave period at the selected locations along Indian coast is also observed to have increased in the future time slice (Figure 4(b)). The wave periods have increased by at least $20 \%$ in most of the locations indicating higher occurrence of swell waves in the future. The increased wave activity along the Indian coast is expected to be a result of the increased extra-tropical winds as indicated by Hemer et al. (2013). Zheng et al. (2018) reported that majority of the Southern Indian Ocean swells propagate into the Bay of Bengal. With future increase in swell generation in the Southern Indian Ocean, it may be expected that the wave heights along the east coast of India would increase (as observed in our analysis). Aboobacker et al. (2011) observed that the swell heights are higher along the Gujarat and Maharashtra coasts and lower along the southwest coast of India, indicating that the open coasts of these two states are highly influenced by 'shamal swells'. Shamal swells are generated as a result of the strong north-westerly winds, called shamal winds, in the Arabian Peninsula and north western Arabian Sea. In our analysis also, we find similar higher waves along Gujarat, compared to other west coast locations. The comparatively lower waves along the south-west coast of India (in both time slices) are a result of the disruption of the shamal and the Southern Indian Ocean swells, which may be initiated by the cooler north-east monsoon winds (Zheng et al. 2018). 


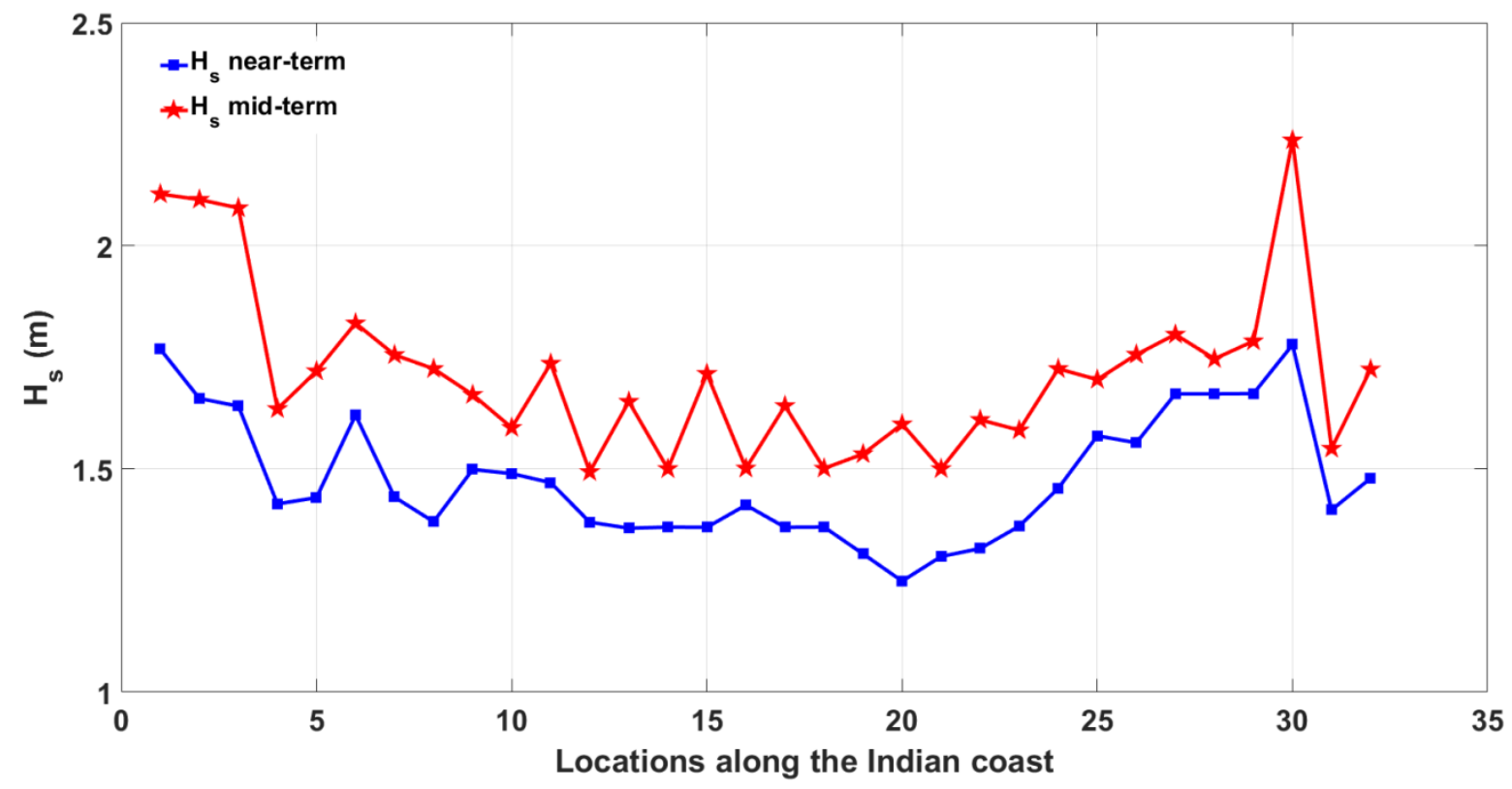

(a)

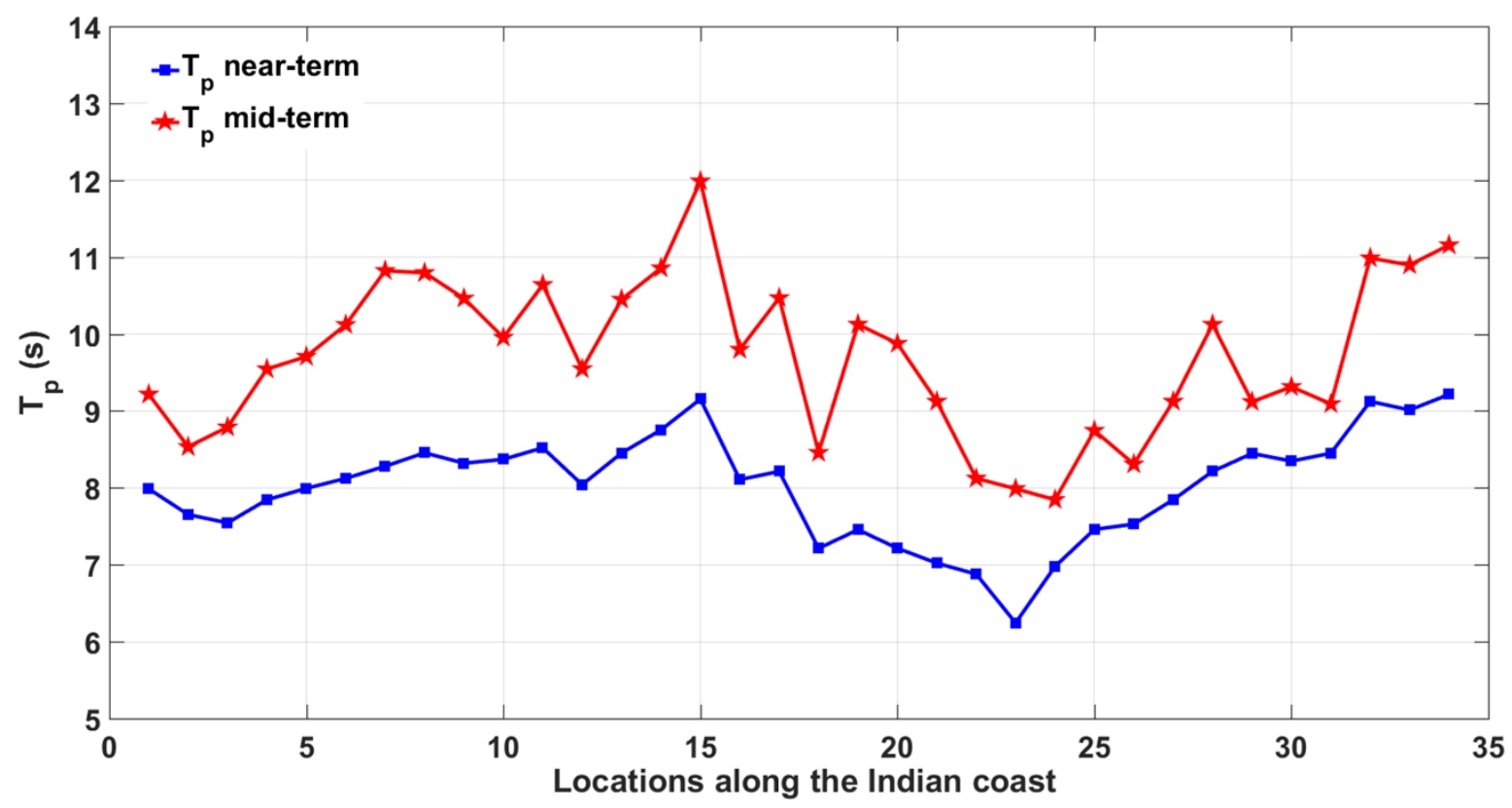

(b)

Figure 4: Time slice average of (a) $\mathrm{H}_{\mathrm{s}}$ and (b) $\mathrm{T}_{\mathrm{p}}$ at selected locations along the Indian coast

As longshore transport is sensitive to wave direction, the present and future wave directions were also analysed at all the locations and presented in Table 1. The wave spectrum is represented by 16 directional sectors: north $(\mathrm{N})$, north-northeast (NNE), northeast $(\mathrm{NE})$, east-northeast (ENE), east (E), east-southeast (ESE), southeast (SE), south-southeast (SSE), south (S), south-southwest (SSW), southwest (SW), west-southwest (WSW), west 
(W), west-northwest (WNW), northwest (NW), and north-northwest (NNW). Figure 5 summarise the annual average wave heights and directions for present and future time slices, at representative locations along the west (locations 2 and 5) and east (locations 23 and 31) coasts of India. We observed that at almost all the locations, the future wave height and direction change with variable magnitudes. For example, at location 2, along Gujarat coast, the predominant wave direction in the near-term wave climate is from SW (mean $=225^{\circ}$ ), whereas, in the future the directional characteristics of the waves are quite different. The spread of incoming waves has increased and waves are predominantly from S-SW (Figure 5(a)). In fact, future waves show two predominant directions of arrival, $S$ (mean $=187^{\circ}$ ), and SW $\left(\right.$ mean $\left.=223^{\circ}\right)$. Similarly, at location 5, along Maharashtra coast, the incoming future waves are observed to have spread when compared to near-term wave climate (Figure 5(b)). The predominant wave direction in the present wave climate is observed to be around $300^{\circ}$ with waves spread between WNW-NW. However, for the future time slice, the predominant wave direction changes and the spread is between W-NW, with two predominant wave directions, $\mathrm{W}\left(\right.$ mean $\left.=270^{\circ}\right)$ and $\mathrm{WNW}\left(\right.$ mean $\left.=300^{\circ}\right)$. In contrast to the trends found at locations 2 and 5, at location 23 (along Andhra Pradesh coast) there is a slight reduction in the spread of wave approach (Figure 5(c)). The present wave direction is spread between ESSE, with two predominant directions, whereas future waves are expected to cluster and approach from ESE-SSE. However, the future wave climate is expected to maintain the two predominant wave directions of the present climate. In the present wave climate, waves arrive from the two predominant directions, $90^{\circ}-112.5^{\circ}$ and $135^{\circ}-158^{\circ}$, whereas, in future wave climate, waves are expected to arrive from $112.5^{\circ}-124^{\circ}$ and $135^{\circ}-158^{\circ}$, which implies narrowed wave direction spread. Location 31, along Odisha coast, also experiences two predominant wave directions, $124^{\circ}-158^{\circ}\left(\right.$ mean $\left.=147^{\circ}\right)$ and $168^{\circ}-192^{\circ}\left(\right.$ mean $\left.=183^{\circ}\right)($ Figure $5(d)$ ). Both near- and mid-term waves arrive from these two predominant directions, but the majority of future waves in the " $124^{\circ}-158^{\circ}$ " sector, are observed to be clustered from SSE, making the future mean wave direction in this sector to be $155^{\circ}$. Similar changes in future mean wave direction and spread of incoming waves is observed for other locations as well. In general, few locations are expected to experience clustering of future waves and others might experience spreading of incoming waves by as much as $22.5^{\circ}$. At some locations, (e.g. location 2), the future waves even show multiple predominant directions as compared to the present climate. 
It may be noted from Figure 5 (and from the analysis of other locations, given in Table 1) that majority of the locations are likely to experience shifting of mean wave direction to a more southerly orientation. This implies that more southerly swells are expected to arrive from the Southern Indian Ocean in the future time slice. The projected changes in wave directions shown here are in broad agreement with the larger scale projections of Hemer et al. (2013), where it was concluded that future wave directions are expected to become more southerly.

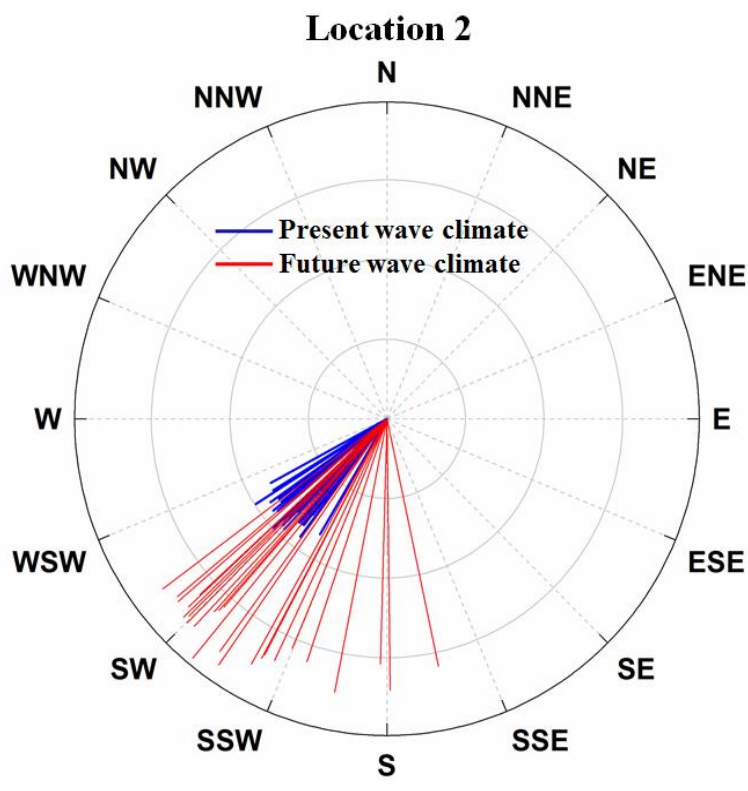

(a)

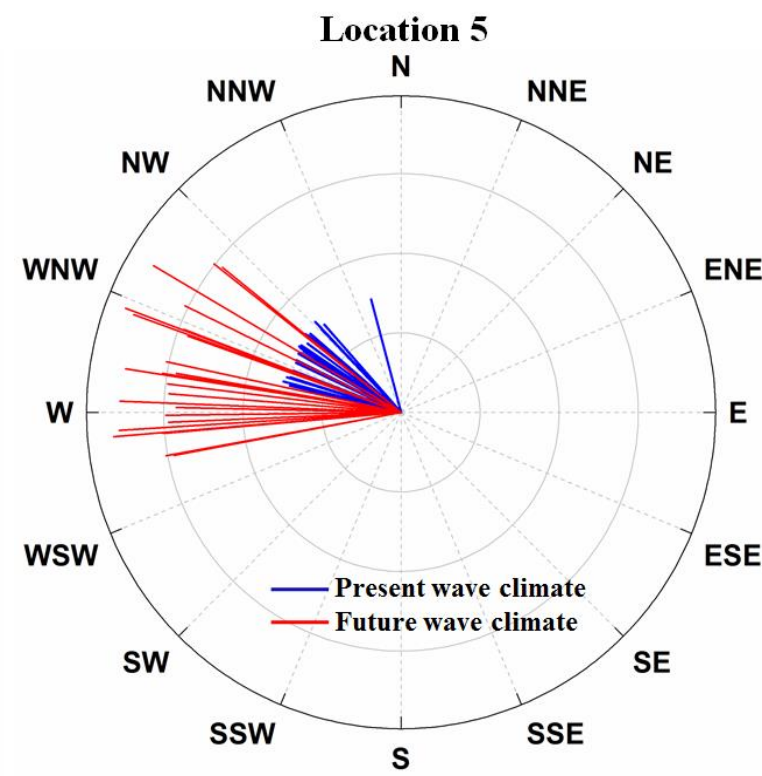

(b)

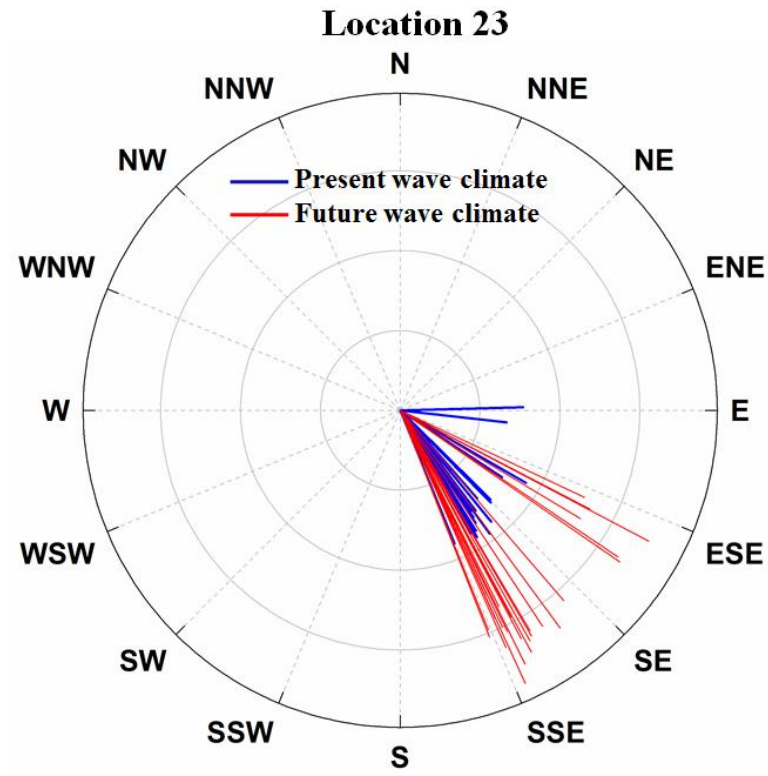

(c)

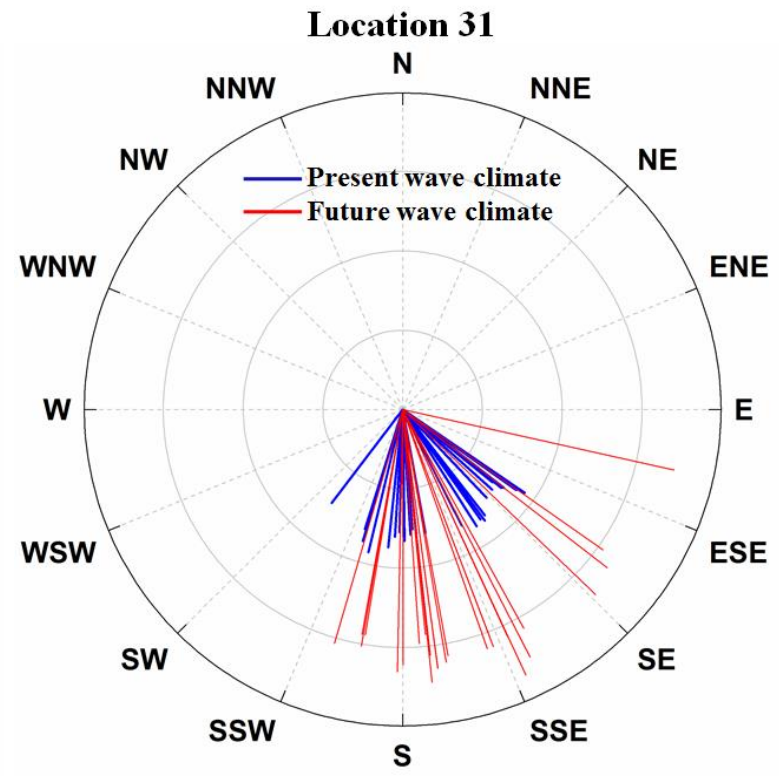

(d) 
Figure 5: Comparison between near- and mid-term annual average $H_{s}$ and $\theta_{m}$ at representative locations along the west (locations 2 and 5) and east (locations 23 and 31) coasts of India

Table 1: Time slice average of wave directions at the selected locations

\begin{tabular}{|c|c|c|c|}
\hline Locations & $\begin{array}{c}\text { Wave } \\
\text { direction }\left(^{\circ}\right) \\
\text { (near-term) }\end{array}$ & $\begin{array}{c}\text { Wave } \\
\text { direction }\left(^{\circ}\right) \\
(\text { mid-term) }\end{array}$ & Remark \\
\hline 1 & 220 & 218 & No significant change observed \\
\hline 2 & 226 & 187,223 & $\begin{array}{l}\text { Waves arrive from } S W \text { in present climate, } \\
\text { whereas they spread between } S-S W \text { in future }\end{array}$ \\
\hline $3^{\#}$ & 234 & 205 & $\begin{array}{l}\text { Waves arrive from } S W \text { in present climate, } \\
\text { whereas mean waves shift to SSW in future }\end{array}$ \\
\hline $4^{\#}$ & 208 & 204 & No significant change observed \\
\hline $5^{\#}$ & 303 & 270,300 & $\begin{array}{l}\text { Future shamal swells tend to become more } \\
\text { westerly }\end{array}$ \\
\hline $6^{\#}$ & 212,275 & 195,278 & $\begin{array}{l}\text { Shamal swells remain westerly, southern swells } \\
\text { become more southerly }\end{array}$ \\
\hline 7 & 208 & 196 & More southerly swells are expected in future \\
\hline 8 & 213 & 218 & No significant change observed \\
\hline 9 & 212 & 215 & No significant change observed \\
\hline 10 & 215 & 225 & More waves are expected from SW in future \\
\hline 11 & 220 & 223 & No significant change observed \\
\hline 12 & 224 & 231 & More south westerly waves expected in future \\
\hline 13 & 233 & 242 & More south westerly waves expected in future \\
\hline 14 & 235 & 248 & More waves expected from WSW \\
\hline 15 & 215 & 207 & More southerly swells are expected in future \\
\hline 16 & 208 & 205 & No significant change observed \\
\hline 17 & 192 & 209 & More waves expected from SW \\
\hline 18 & 185 & 193 & No significant change observed \\
\hline 19 & 197 & 202 & No significant change observed \\
\hline 20 & 138 & 146 & More waves expected from SSE \\
\hline 21 & 135 & 149 & More waves expected from SSE \\
\hline 22 & 112 & 147 & More waves expected from ESE-SSE \\
\hline $23^{*}$ & 150,100 & 148,114 & More waves expected to shift to ESE \\
\hline 24 & 168 & 185 & More southerly waves expected \\
\hline 25 & 158 & 163 & No significant change observed \\
\hline $26^{*}$ & 128,189 & 159,194 & More mean waves from SSE expected in future \\
\hline $27^{*}$ & 108,188 & 97,194 & More mean waves from E expected in future \\
\hline $28^{*}$ & 130,200 & 138,197 & No significant change observed \\
\hline $29^{*}$ & 128,186 & 142,178 & More waves are expected from SE in future \\
\hline $30^{*}$ & 135,196 & 147,183 & No significant change observed \\
\hline $31^{*}$ & 147,183 & 155,185 & No significant change observed \\
\hline $32^{*}$ & 128,215 & 147,203 & More waves are expected from SE in future \\
\hline $33^{*}$ & 155,228 & 162,215 & Mean waves shift to SSW in future \\
\hline
\end{tabular}


\begin{tabular}{|l|l|l|l}
$34^{*}$ & 168,230 & 176,224 & No significant change observed
\end{tabular}

\#These locations are heavily influenced by shamal swells arriving from NW

*These locations may be highly influenced by both SW and NE monsoon seasons, hence two predominant directions

\section{Present and future coastal morphodynamics}

With increased wind speeds and wave heights over the Indian Ocean region, the distribution of energy across all wave types will increase and consequently have an impact on coastal processes such as sediment transport. The impact of changing wave climate on littoral drift was determined by estimating the longshore transport rates for both time slices at the selected locations. Average longshore transport rates at each location for both time slices was estimated using Eq. 1 and is presented in Figure 6(a). Positive or negative values of longshore transport indicate that the net longshore transport direction is towards north or south, respectively. In general, the rate of longshore transport is high along the Indian coast (of the order $10^{5} \mathrm{~m}^{3}$ ). Much of the west coast of India (except few locations) shows a southward (ve) movement of sediments, whereas, a northward (+ve) movement of sediments was observed at all the locations along the east coast (Figure 6(a)). Locations 3, 33 and 34 (shown in Figure 1) are not considered for longshore sediment transport modelling due to the complex process at these points as explained earlier. The sediment transport rates at locations $5,6,18,19$, and 20 were observed to be less pronounced, compared to all other locations. It was noticed from our analysis that locations 5 (Figure 5(b)) and 6, experience more westerly waves (in this case, almost normally incident to the coast) in the future time slice. Arrival of more normally incident waves indicates that the beaches may reform into swash aligned beaches rather than the currently drift aligned beaches. Similarly, our longshore transport analysis show that locations 5 and 6 will experience a reduction in net longshore transport in the future time slice. Locations 18, 19 and 20 are sheltered due to the presence of Sri Lanka and experience lower wave heights approaching the shadow region from south, probably causing the lower rates of sediment transport. All the other locations are observed to follow the general trend of longshore transport rates in the future time slice. With increased wave activity along the Indian coast, the distribution of energy is expected to be higher at the beaches leading to increased rates of sediment transport in the future years, although this may be modified by changes in wave direction, and the two need to be considered together for a full picture. The increase in sediment transport volume is found to be less significant at the selected locations than from a consideration of changes in wave height alone. The results 
obtained here are in broad agreement with other studies carried out at much local scale like that of Chowdhury and Behera (2017). The average longshore transport in the central west coast of India (location 10) was found to be 441,205 $\mathrm{m}^{3} /$ year, whereas it was reported to be $437,200 \mathrm{~m}^{3} /$ year by Chowdhury and Behera (2017). Although the longshore transport rates at most of the locations may be in broad agreement with the local scale analysis, variation in the results are expected at some locations due to the differences in methods adopted and periods of computation, accuracy of coastline orientation, and wave climate scenario. The estimates of longshore transport are dependent upon the choice of bulk transport formula and some uncertainty in this respect is to be accepted, (Bayram et al. 2007; Dastgheib et al. 2016). The results of this study should be viewed in this context and as such provide information for broadscale practical applications rather than detailed design. Figure 6(b) shows the difference/change between present and future longshore transport rates depicting the effect of future wave climate on the sediment transport rates. Most of the locations show a net change in longshore transport rate by more than $0.5 \times 10^{5} \mathrm{~m}^{3} /$ year, (mean $\sim 1 \times 10^{5} \mathrm{~m}^{3} /$ year). While not large in comparison the absolute values of sediment transport at these locations it could still cause significant changes in shoreline position and orientation over the period of a few years.

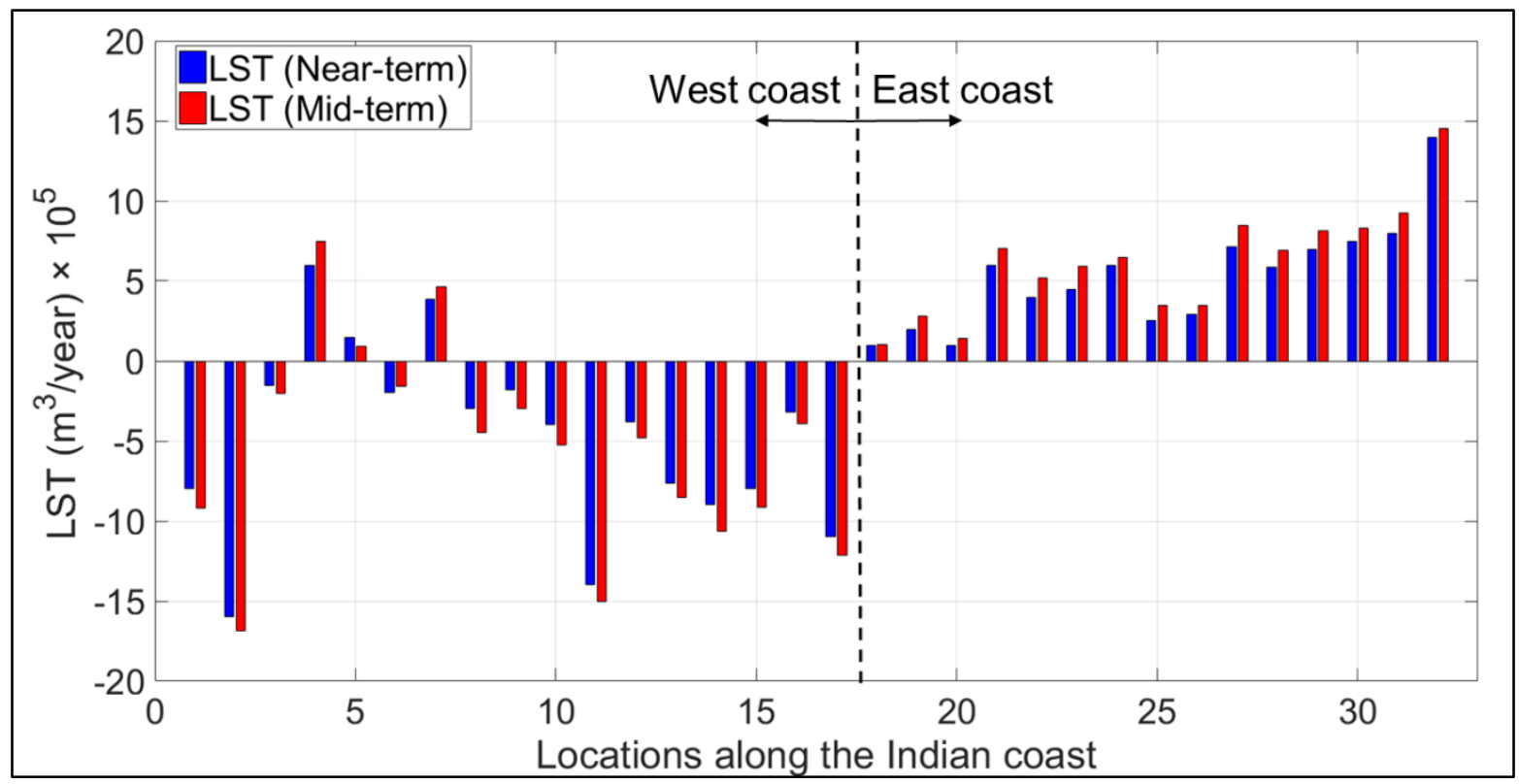

(a) 


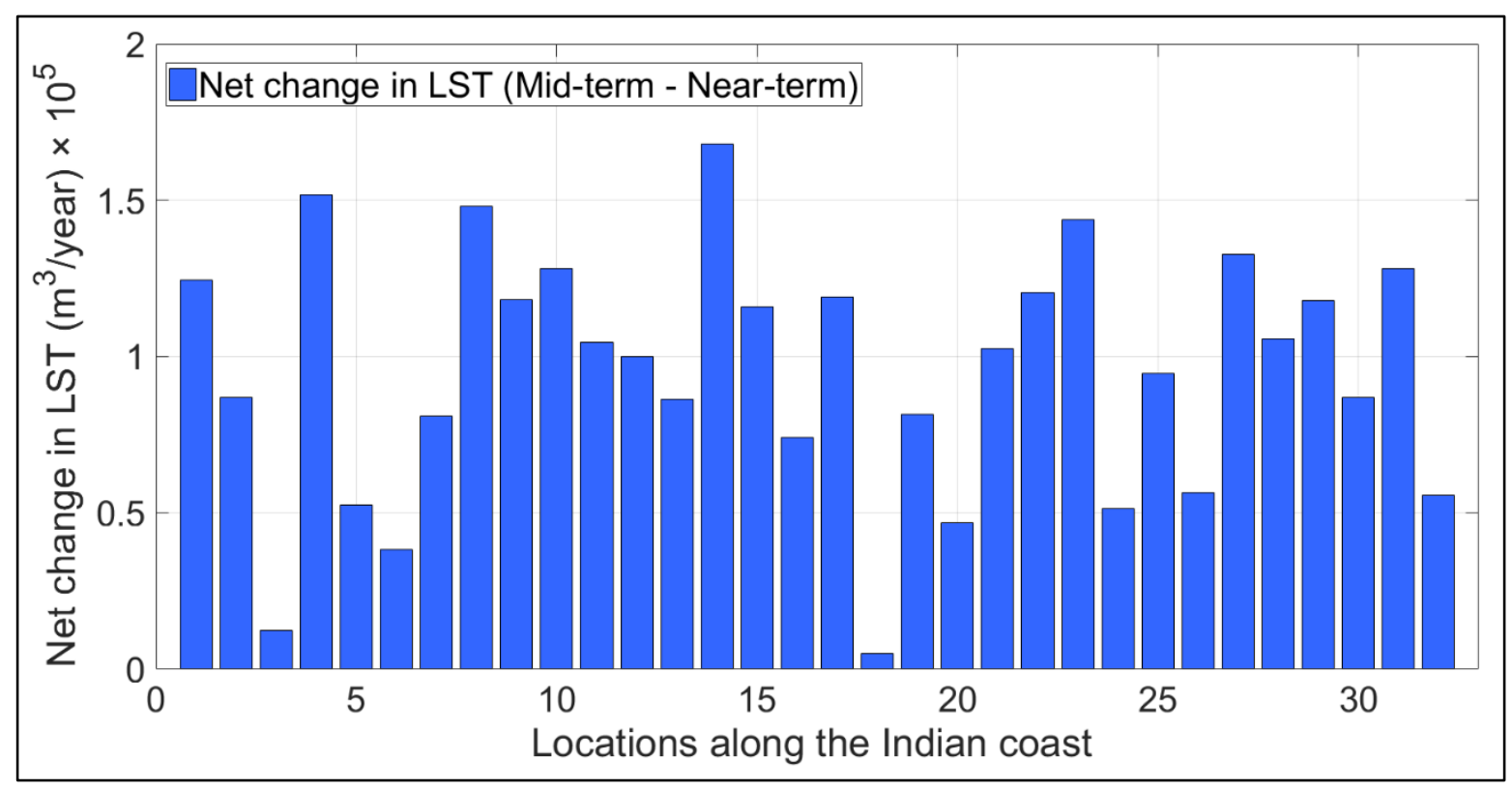

(b)

Figure 6: (a) Time slice average of longshore transport rates extracted at each selected location along the Indian coast, positive values indicate northward movement of sediments and vice versa, and (b) net change in longshore transport rates between mid- and near-term

\section{Classification of coastal stretches under present and future climate scenario}

Sediment transport plays an important role in maintaining the orientation of shorelines by adjusting the inflowing and outflowing sediments through the processes of erosion and accretion. The tendency of the shoreline segments towards erosion/accretion during both the time slices was calculated using Eq. 3 and is given in Figure 7. Commensurate with the broad scale approach these results are presented in a relatively qualitative manner. The segments are classified as: erosive (marked in red), accretive (marked in yellow) or stable (marked in blue). It is observed that processes in certain areas (like erosion along northern coast of Andhra Pradesh and central coast of Maharashtra; accretion along Kerala and northern and southern Tamil Nadu, etc.) are well detected in our study (Figure 7(a)) as reported by the CWC (2016) report (Figure 3). Our analysis also detects certain local scale rates of erosion/accretion presented by other studies. For example, the rate of accretion along Karwar, Karnataka (3.9 m/year, in the present study) is in broad agreement with the rate of accretion (4.4 m/year) presented in Chowdhury and Behera (2019), where satellite images were used to detect changes in shoreline evolution. However, there are also some local differences with respect to the results presented in the CWC (2016) report (Figure 3). The results of the present study (Figure 7(a)) show a greater fidelity of areas of erosion/accretion 
along the east coast of India, and comparatively more stable pockets of beaches along the west coast of India (for example, along southern Maharashtra, and Goa). However, some of the localized areas of erosion/accretion documented in the CWC (2016) report are not captured in our study, which could be due to differences in the spatial and temporal scales, wave climate, and the methodology adopted. The results could be improved by considering more detailed geographical features of the study area like the presence of cliffs, estuaries and creeks, local bathymetry, and others. The local features were not considered in our study keeping the focus on projection of changes in net sediment transport rate on a regional scale. In addition, the use of Kaczmarek et al. (2005) sediment transport model (applicable to sandy coasts only) was justified by considering large stretches of coasts.

The classification of selected coastal stretches for future time slice (2041-2070) show some minor changes with respect to that of the present time slice (Figure 7(b)), however no major changes in the overall trend is observed. A more detailed analysis of the future trend indicates that some stretches maintain the similar tendency of beach evolution, as that in the present climate. For example, the considered stretches along the northern coast of Gujarat, coast of Goa, southern Maharashtra, and parts of Karnataka, tend to maintain the stable beaches in future climate as well. Similarly, much of the coasts of central Maharashtra, Andhra Pradesh, and parts of southern coast of Tamil Nadu and West Bengal, are expected to continue eroding at similar rates, putting these coastal areas under increased multiple threats of land degradation, loss of resources, and disrupted coastal and biological processes and making them vulnerable to climate change. Also, parts of coasts along Gujarat, Kerala, Tamil Nadu, and Odisha are observed to maintain their accretion rates in the future climate. The stable and accretive beaches in future climate can be considered "favourable", as they help in maintaining beach width and hence promote protection and leisure activities. In such a scenario, the southern coastal tips of Kerala and Tamil Nadu, and parts of northern and central coast of Odisha, are expected to have "improved" coastal stretches by the end of the future time slice (2041-2070), as the stretches are observed to have changed from either 'erosive/accretive to stable' or 'erosive to accretive'. However, the impact of accretion on other coastal and biological processes has not been investigated in this study.

The present analysis shows that about $35 \%$ of the total stretch of coastline of India considered here, would remain unaffected by the future climate change, i.e., it would maintain the same trend of beach evolution in the future time slice, irrespective of the predicted changes in climate. It is expected that $20 \%$ of the beaches would have "worsened" 
in the future, as the rate of erosion along such stretches is expected to increase. However, the remaining $45 \%$ of the coastline is expected to "improve" with increase in the percentage of stable and accretive beaches. Table 2 summarise the state-wise status of beaches in both the present and future climate scenarios. It is observed that about $40 \%$ of the coasts of Karnataka, and Kerala are expected to have stable beaches in the future climate, and at the same time more than $50 \%$ of Maharashtra, Andhra Pradesh and West Bengal coasts would experience erosion. The maximum amount of erosion is expected along the coasts of Andhra Pradesh and West Bengal (67\%), and the maximum accretion is expected along the coast of Gujarat (45\%). The least amount of erosion is expected along the coasts of Goa (10\%). The highest percentage of stable beaches are expected along the coast of Goa $(\sim 75 \%)$ in both the wave climates. The impact of changing climate and wave parameters, mainly wave direction, in the future time slice is observed along majority of the Indian coast. Overall, the study shows about $30 \%$ of the affected coasts would "worsen" and $70 \%$ would "improve". However, the net change in annual longshore transport rates is not found to be significant along the selected coastal stretches.

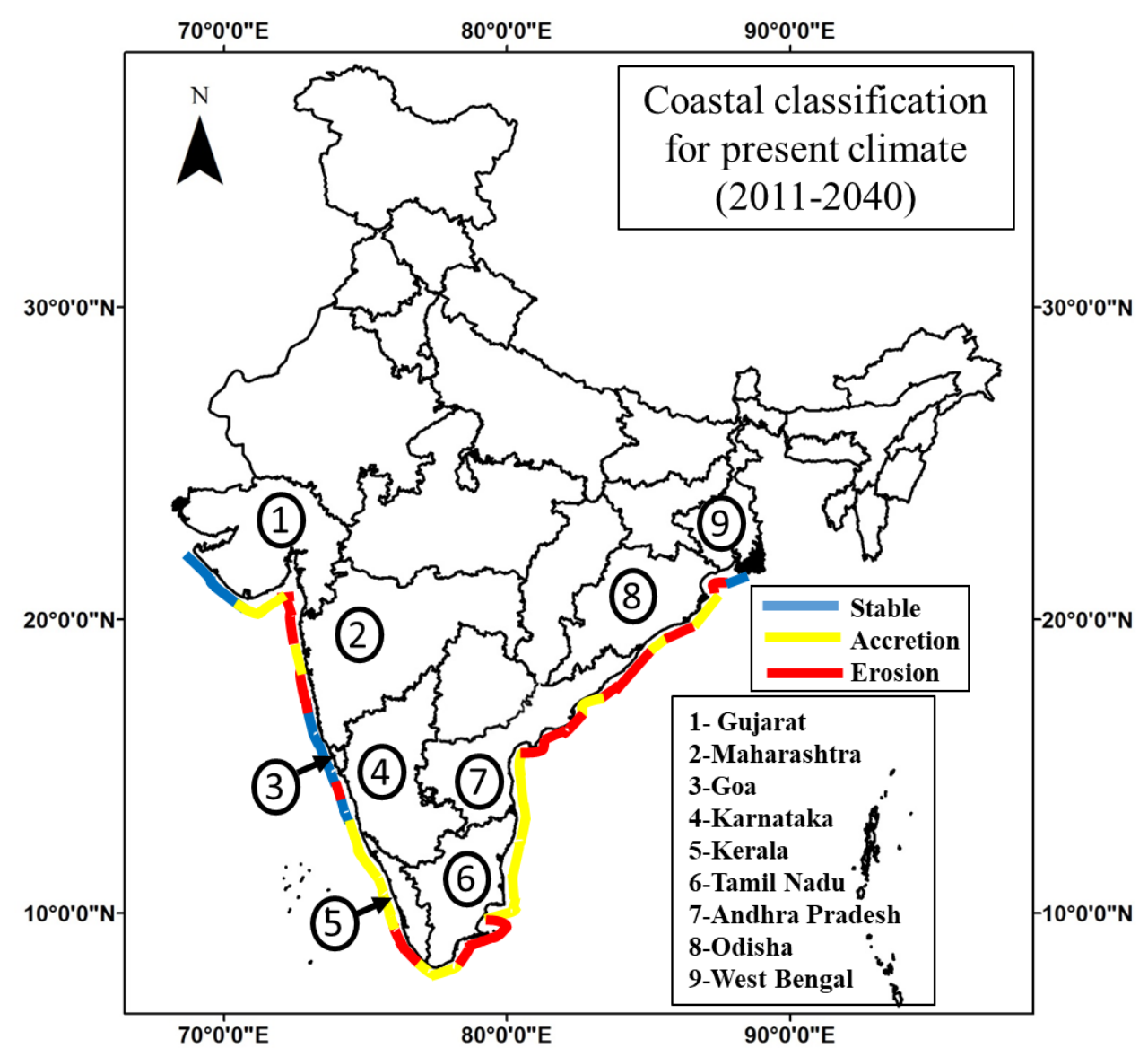

(a) 


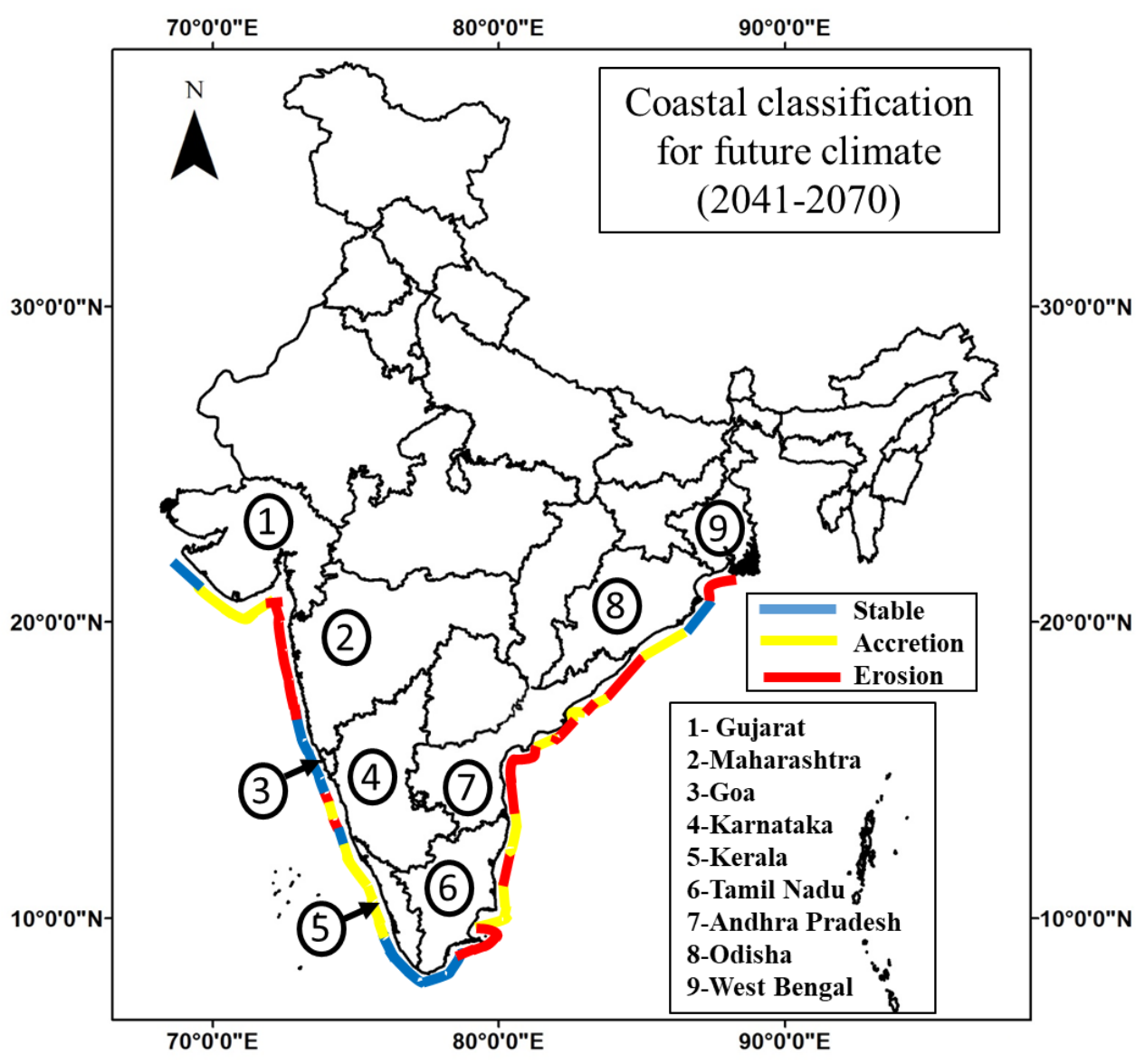

(b)

Figure 7: Classification of coastal stretches along India as erosive, accretive and stable beaches for the (a) near-term and (b) mid-term

Table 2: Present and future status of beaches along India

\begin{tabular}{|c|c|c|c|c|c|c|}
\hline \multirow{2}{*}{ State Name } & \multicolumn{2}{|c|}{ Erosion (\%) } & \multicolumn{2}{c|}{ Accretion (\%) } & \multicolumn{2}{c|}{ Stable (\%) } \\
\cline { 2 - 7 } & Near-term & Mid-term & Near-term & Mid-term & Near-term & Mid-term \\
\hline Gujarat* & 10 & 18 & 25 & 45 & 65 & 37 \\
\hline Maharashtra & 44 & 54 & 22 & 8 & 34 & 38 \\
\hline Goa & 10 & 10 & 15 & 10 & 75 & 80 \\
\hline Karnataka & 27 & 33 & 30 & 27 & 43 & 40 \\
\hline Kerala & 28 & 18 & 62 & 43 & 10 & 39 \\
\hline Tamil Nadu & 37 & 42 & 51 & 34 & 12 & 24 \\
\hline Andhra Pradesh & 48 & 67 & 46 & 29 & 6 & 4 \\
\hline Odisha & 36 & 46 & 44 & 34 & 20 & 20 \\
\hline West Bengal* & 65 & 67 & 10 & 18 & 25 & 15 \\
\hline
\end{tabular}

*Represents the length of coastline considered in this study. 


\section{Conclusions}

Future wave heights were observed to be higher than the present at most of the selected locations. These locations showed significant increase in wave heights, which may have profound impacts on the coastal morphodynamics. For example, higher rates of increase in $\mathrm{H}_{\mathrm{s}}$ was observed along Gujarat, Maharashtra, Tamil Nadu, Andhra Pradesh, Odisha, and West Bengal. It was observed that the wave periods would increase by at least $20 \%$ along much of the Indian coast, indicating higher occurrence of swell waves in the future. It was also observed that the majority of the locations are likely to experience shifting of mean wave directions to a more southerly orientation. This implies that more swells are expected from the Southern Indian Ocean in the future climate. Many locations are expected to experience a shift in wave directions by as much as $22.5^{\circ}$. Some locations also show a more clustered wave climate in the future, indicating excessive erosion. Such major changes in wave climate are likely to impact several coastal processes and coastal morphology. Our analysis of sediment transport rates in both time slices confirm the impact of climate change on coastal sediment transport along the Indian coast.

The selected locations show similar trend in future sediment transport rates, as that of the present. Much of the west coast of India shows a southward movement of sediments, whereas, a northward movement of sediments was observed at all the locations along east coast. The future longshore transport rates at many places are observed to be more or less translated to higher values, however the change is less pronounced at some locations. We also observed that some beaches (locations 5 and 6) along the west coast of India are becoming more swash aligned due to increase in westerly waves in the future.

Our analysis indicates that about $35 \%$ of the total coastal stretches considered, would remain unaffected due to climate change. A majority of the Indian coast would be affected mainly due to changes in wave direction. About $30 \%$ of the affected coast is expected to "worsen" and about 70\% would "improve". A more detailed analysis showed that about 40\% of the coasts of Maharashtra, Karnataka, Kerala and West Bengal would become stable, and more than $40 \%$ of Odisha, Tamil Nadu and West Bengal coast would experience erosion, in the future climate. The maximum amount of erosion was detected along the coasts of Andhra Pradesh and Odisha, maximum accretion along Gujarat, and the highest percentage of stable beaches were observed along the coast of Goa. 
Our results imply that it is important to consider the changes in mean wave directions along with wave heights, to analyse the potential impacts of climate change on coastal processes and morphodynamics, and designing coastal management policies. The results presented here are intended as a preliminary investigation into the broad scale trends of shoreline change in the face of climate change. The results and conclusions are constrained by the modelling assumptions. The longshore transport rates could be computed with instantaneous wave characteristics for a higher temporal resolution investigation. However, the present study used annual average wave parameters for estimation of longshore transport which is acceptable for the broad scale nature of the study. This study is the first of its kind of this region and is intended to assist other researchers and policy makers wishing to progress in this direction. A way forward for the future studies could be improvement of uncertainty estimates in wave projection, by using more sophisticated wind projections (on a much higher resolution). Another aspect of future research in this regard could be including impact of sea level changes on future nearshore wave climate on a local/regional scale.

\section{Acknowledgement}

The authors wish to thank the anonymous reviewers whose constructive comments helped to improve the manuscript. PC wishes to thank the Department of Science and Technology, Government of India and the Centre of Excellence in Climate Studies, IIT Bombay, for funding her $\mathrm{PhD}$ research work through grant number DST/CCP/PR/06/2011 (G). MRB acknowledges the support of Department of Science and Technology (DST) Grant No. DST/INT/UK/P-165/2017 as part of the DST UKIERI Thematic Partnership titled "Longshore Sediment Transport Simulations in a Changing Climate". DR acknowledges the support of British Council Grant No. IND/CONT/G/2017-18/32 as part of the DST UKIERI Thematic Partnership titled "Longshore Sediment Transport Simulations in a Changing Climate". All the authors would like to acknowledge the World Climate Research Programme's Working Group on Coupled Modelling, which is responsible for CMIP, and we thank the climate modelling groups, CSIRO, CNRM, GFDL and IPSL, for producing and making available their model output. The authors also acknowledge European Centre for Medium Range Weather Forecasts (ECMWF) for providing ERA wave hindcasts (www.ecmwf.int). 


\section{Reference}

1. Aboobacker VM, Vethamony P, Rashmi R (2011) "Shamal" swells in the Arabian Sea and their influence along the west coast of India. Geophysical Research Letters, 38(3). DOI:10.1029/2010GL045736

2. Adams PN, Inman DL, Lovering JL (2011) Effects of climate change and wave direction on longshore sediment transport patterns in Southern California. Climatic Change, 109(1), 211-228. https://doi.org/10.1007/s10584-011-0317-0

3. Almar R, Kestenare E, Reyns J, Jouanno J, Anthony EJ, Laibi R, Hemer M, Du Penhoat Y, Ranasinghe R (2015) Response of the Bight of Benin (Gulf of Guinea, West Africa) coastline to anthropogenic and natural forcing, Part1: Wave climate variability and impacts on the longshore sediment transport. Continental shelf research, 110, 48-59. https://doi.org/10.1016/j.csr.2015.09.020

4. Bayram A, Larson M, Hanson H (2007) A new formula for the total longshore sediment transport rate. Coastal Engineering, 54(9), 700-710. https://doi.org/10.1016/j.coastaleng.2007.04.001

5. Bengtsson L, Hodges KI, Roeckner E (2006) Storm tracks and climate change. J Clim 19, 3518-3543. https://doi.org/10.1175/JCLI3815.1

6. Bertin X, Castelle B, Chaumillon E, Butel R, Quique R (2008) Longshore transport estimation and inter-annual variability at a high-energy dissipative beach: St. Trojan beach, SW Oléron Island, France. Continental Shelf Research, 28(10-11), 1316-1332. https://doi.org/10.1016/j.csr.2008.03.005

7. Castelle B, Turner IL, Bertin X, Tomlinson R (2009) Beach nourishments at Coolangatta Bay over the period 1987-2005: impacts and lessons. Coastal Engineering, 56(9), 940-950. https://doi.org/10.1016/j.coastaleng.2009.05.005

8. CERC (1984) Shore Protection Manual. Vols I and II. Coastal Engineering Research Center. U.S. Army Corps of Engineers, Washington, DC. U.S. Government Printing Office, Vicksburg.

9. Chowdhury P, Behera MR (2017) Effect of long-term wave climate variability on longshore sediment transport along regional coastlines. Progress in Oceanography, 156, 145-153. https://doi.org/10.1016/j.pocean.2017.06.001

10. Chowdhury P, Behera MR (2018) Evaluation of CMIP5 and CORDEX derived wave climate in Indian Ocean. Climate Dynamics, 52(7-8), 4463-4482. 
11. Chowdhury P, Behera MR (2019) Nearshore Sediment Transport in a Changing Climate. In: Venkataraman C., Mishra T., Ghosh S., Karmakar S. (eds) Climate Change Signals and Response. Springer, Singapore (ISBN: 978-981-13-0279-4). 147160. https://doi.org/10.1007/978-981-13-0280-0_9

12. Chowdhury P, Behera MR, Reeve DE (2019) Wave climate projections along the Indian coast. International Journal of Climatology. https://doi.org/10.1002/joc.6096

13. Dastgheib A, Reyns J, Thammasittirong S, Weesakul S, Thatcher M, Ranasinghe R (2016) Variations in the wave climate and sediment transport due to climate change along the coast of Vietnam. Journal of marine science and engineering, 4(4), 86.

14. DHI, 2014. Mike 21- Spectral Waves. Denmark: Developing by Danish Hydraulic Institute.

15. Grabemann I, Weisse R (2008) Climate change impact on extreme wave conditions in the North Sea: an ensemble study. Ocean Dynamics, 58(3-4), 199-212. https://doi.org/10.1007/s10236-008-0141-X

16. Güner HA, Yüksel Y, Çevik EÖ (2011) Longshore sediment transport—field data and estimations using neural networks, numerical model, and empirical models. Journal of Coastal Research, 29(2), 311-324.

17. Hallermeier RJ (1978) Uses for a calculated limit depth to beach erosion. Coastal Engineering, 1493-1512.

18. Hemer MA, Katzfey J, Trenham CE (2013) Global dynamical projections of surface ocean wave climate for a future high greenhouse gas emission scenario. Ocean Modell. 70, 221-245. https://doi.org/10.1016/j.ocemod.2012.09.008

19. Kaczmarek LM, Ostrowski R, Pruszak Z, Rozynski G (2005) Selected problems of sediment transport and morphodynamics of a multi-bar nearshore zone. Estuar. Coast. Shelf Sci. 62 (3), 415-425. https://doi.org/10.1016/j.ecss.2004.09.006

20. Larson M, Hoan LX, Hanson H (2010) Direct formula to compute wave height and angle at incipient breaking. Journal of waterway, port, coastal, and ocean engineering, 136(2), 119-122. DOI: 10.1061/(ASCE)WW.1943-5460.0000030

21. Longuet-Higgins, M.S., 1970. Longshore currents generated by obliquely incident sea waves: 1. Journal of geophysical research, 75(33), 6778-6789. https://doi.org/10.1029/JC075i033p06778

22. Mil-Homens JP, Ranasinghe RWMRJB, Van Thiel de Vries JSM, Stive M.F (2012) Re-assessment and update of bulk longshore sediment transport formulas. ICCE 2012: 
Proceedings of the 33 International Conference on Coastal Engineering, Santander, Spain, 1-6 July 2012.

23. Mori N, Shimura T, Yasuda T, Mase H (2013) Multi-model climate projections of ocean surface variables under different climate scenarios-Future change of waves, sea level and wind. Ocean Engineering, 71, 122-129.

https://doi.org/10.1016/j.oceaneng.2013.02.016

24. Moss R, Babiker W, Brinkman S, Calvo E, Carter T, Edmonds J, Elgizouli I, Emori S, Erda L, Hibbard K, Jones RN (2008) Towards New Scenarios for the Analysis of Emissions: Climate Change, Impacts and Response Strategies. http://vuir.vu.edu.au/id/eprint/4819

25. Mukhopadhyay R, Karisiddaiah SM (2014) The Indian Coastline: Processes and Landforms. In Landscapes and landforms of India (91-101). Springer Netherlands.

26. Nicholls RJ, Brown S, Goodwin P, Wahl T, Lowe J, Solan M, Godbold JA, Haigh ID, Lincke D, Hinkel J, Wolff C (2018) Stabilization of global temperature at $1.5 \mathrm{C}$ and 2.0 C: implications for coastal areas. Philosophical Transactions of the Royal Society A: Mathematical, Physical and Engineering Sciences, 376. https://doi.org/10.1098/rsta.2016.0448

27. Pattiaratchi C, Hegge B, Gould J, Eliot I (1997) Impact of sea-breeze activity on nearshore and foreshore processes in south western Australia. Continental Shelf Research, 17(13), 1539-1560. https://doi.org/10.1016/S0278-4343(97)00016-2

28. Remya PG, Kumar R, Basu S, Sarkar A (2012) Wave hindcast experiments in the Indian Ocean using MIKE $21 \mathrm{SW}$ model. Journal of earth system science, 121(2), 385-392. https://doi.org/10.1007/s12040-012-0169-7

29. Slott JM, Murray AB, Ashton AD, Crowley TJ (2006) Coastline responses to changing storm patterns. Geophysical Research Letters, 33(18). https://doi.org/10.1029/2006GL027445

30. Status Report on Coastal Protection \& Development in India, Central Water Commission (CWC), New Delhi, India, 2016. http://cwc.gov.in/CPDACWebsite/Paper_Research_Work/Status_Report_on\%20_Coastal_Protection_and\%20 Development_in\%20_India_2016.pdf (accessed: May, 2018)

31. U.S. Army Corps of Engineers (2002) Coastal Engineering Manual. Engineer Manual 1110-2-1100, U.S. Army Corps of Engineers, Washington, D.C. 
32. Wang X, Swail V, Zwiers F, Zhang X, Feng Y (2009) Detection of external influence on trends of atmospheric storminess and northern oceans wave heights. Clim Dyn 32(2):189-203. https://doi.org/10.1007/s00382-008-0442-2

33. Wang XL, Swail VR (2002) Trends of Atlantic wave extremes as simulated in a 40-yr wave hindcast using kinematically reanalyzed wind fields. Journal of climate, 15(9), 1020-1035.

34. Zacharioudaki A, Reeve DE (2011) Shoreline evolution under climate change wave scenarios. Climatic change, 108(1-2), 73-105. https://doi.org/10.1007/s10584-590 $\underline{010-0011-7}$

35. Zheng CW, Li CY, Pan J (2018) Propagation route and speed of swell in the Indian Ocean. Journal of Geophysical Research: Oceans, 123(1), 8-21. DOI: 10.1002/2016JC012585

36. Zsamboky M, Fernández-Bilbao A, Smith D, Knight J, Allan J (2011) Impacts of climate change on disadvantaged UK coastal communities. York, UK: Joseph Rowntree Foundation. 